\title{
Corruption in Relation to Poverty and Inequality Indicators at a Global Level
}

\author{
Pîrvan CARMEN \\ The Bucharest University of Economic Studies \\ Doctoral programs in Economics and Law \\ Accounting Doctoral School, Bucharest \\ Romania \\ Nișulescu-Ashrafzadeh ILEANA \\ The Bucharest University of Economic Studies \\ Bucharest University of Economic Studies Council for Doctoral Studies (CSUD) \\ Bucharest, Romania
}

\begin{abstract}
During 2017, for the third consecutive year, the corruption perceptions index highlights the fact that most countries are making little or no progress at all in eliminating corruption. Corruption is a major problem faced by all countries of the world, a widespread phenomenon, and the low number of cases where corruption has been eradicated leads to the conclusion that this scourge is persistent one, and difficult to eliminate. This paper aims to determine how the Corruption Perception Index (CPI) has evolved at a regional and global level, as well as to analyze the level of corruption in relation to a country's development level, and also the level of poverty and inequality as predictors of corruption.
\end{abstract}

Keywords: corruption, corruption perception index, gross domestic product, poverty.

Classification JEL: C40, D12, O12

\section{Introduction}

Corruption affects the states' efforts to recover from a bad financial situation and the fight against poverty. Equally, corruption erodes democracy, leads to the degradation of society, and to contrasting distributions of wealth or power. (Johnston, 2007)

Broadly speaking, corruption is a departure from morality, honor, and duty. As an expression of the relationship between authorities and citizens, corruption is the discretionary use of position or function by resorting to illicit or illegal means in order to obtain personal or group interests.

Specialist literature on integrity takes into account aspects that create a favorable context for unethical behaviors, identifying different causes that favor the phenomenon of corruption and explaining the differences that exist between different states from this point of view. Thus, transition countries that face the lack of resources and inappropriate pay of officials involved in fighting corruption are more exposed to corruption than rich countries that can allocate resources to anti-corruption and anti-corruption systems and to attracting and retain competent people or to motivate existing ones to be immune to temptation.

Friedrich said that "we are talking about corruption whenever a power holder, a public servant or any public official is determined by financial or other rewards, such as the promise of promotion, which is not prescribed by law, to take action that favors the reward, thereby causing damage to the public and its interests "(Friedrich, 1999). Nye regards corruption as "activities that deviate from the formal duties of a public function in favor of private, pecuniary or status gains obtained by individuals or groups" (Nye, 1961).

Also, the political regime strongly influences the phenomenon of corruption, with presidential regimes being more affected by corruption than parliamentary ones. In this respect, Fred Riggs notes that all presidential regimes, except for the United States, have suffered major crises (coup, civil wars) between 1900 and 1985. On the other hand, only 13 of the parliamentary regimes experienced similar experiences during this period, most of which took place in the interwar period (Germany, Italy, Spain, etc.) (Riggs, 1997) 
The economic outlook for defining corruption provides an explanation for the much higher incidence and the much higher level of violation of public integrity rules in poor countries or in the ones transitioning towards democracy and a market economy, where resources are fewer, the salaries of civil servants are low and law enforcement systems are less effective, the probability of the offender getting punished being less likely. (Radu, L. and Gyula, G., 2010)

"Poverty" is defined as an economic condition generated by both the lack of money and basic living needs such as food, water, utilities and housing. There are different approaches and countless debates on poverty definition, but lack of safe and stable income, able to provide predictability of the continuous meeting of one's basic needs, are the key elements of absolute poverty indicators. Poverty can therefore also be defined as the economic condition of a lack of predictable and stable means to meet the basic needs of living.

The definition and the limits of poverty vary considerably between countries and nations. For example, wealthy countries generally use more generous poverty standards than poor nations. Even among the rich nations, standards are very different. Thus, there is a risk that figures will not ensure comparability between countries, even when the same method is used. (European Commission, 2010)

The Corruption Perceptions Index (CPI) is an instrument launched in 1995 by Transparency International that addresses corruption as a social phenomenon. The CPI is analyzed annually at the level of 180 countries monitored, indicating their position on corruption perceptions. The countries' ranking in the Transparency International ranking is based on a score of 0 to 100 , where 100 is the lowest level of corruption.

The Transparency International Report for 2017 reveals corruption as a burden in more than two-thirds of states, despite attempts to combat global corruption. Reducing corruption is a lengthy process, but in recent years many countries have progressed too little or not at all. Over the past six years, the CPI score has improved significantly in several states, including Côte d'Ivoire, Senegal and the United Kingdom, while in other countries it has fallen, including Syria, Yemen and Australia.

In 2017, New Zealand and Denmark are in the top rankings with a score of 89 and 88 respectively. Syria, South Sudan and Somalia are ranked 14, 12 and 9 points respectively. The region with the best results is Western Europe with an average score of 66 points. The regions with the lowest results are Sub-Saharan Africa (average score 32), Eastern Europe and Central Asia (average score 34). (Transparency International, 2017)

As shown in the annex table no. 1, in terms of the Corruption Perceptions Index 2017, more than two-thirds of the 180 countries and territories are below the average from 0 (very corrupt) to 100 (without corruption).

\section{Research Methodology}

The paper addresses a quantitative research of information collection (descriptive and experimental studies, surveys) and data analysis (statistics, content analysis).

The survey aims to detect how the Corruption Perceptions Index (CPI) has evolved over the period 2010-2017 globally, analyzing the perceptions of corruption per capita GDP and poverty and inequality as predictors of corruption.

The methodology of scientific research is predominantly qualitative and theoretical, and in order to achieve the proposed objectives, we have used specific methods to analyze the content of reports and studies, statistical records, analyzes and publications of various bodies, organizations and institutions such as Transparency International, World Bank, Eurostat. In this regard, we have collected data from Transparency International Global Corruption Barometer, Global Integrity and the European Commission, the European Anti-Fraud Office and the World Bank, with the aim of analyzing corruption-related variables in the world. Variables have been used regarding the dynamics of the corruption phenomenon, such as corruption perceptions index, GDP per capita and poverty as a predictor of corruption, and the indicator of inequality in countries of the world (GINI).

GINI represents "Multi-dimensional set of measures and actions in the fields of social protection, employment, housing, education, health, information and communication, mobility, security, justice and culture, aimed at combating social exclusion" (INSERT, 2014)

\section{Research analysis}

The research starts from the premise that the analysis of the CPI's global evolution is important in the present context from the perspective of understanding and combating this phenomenon. 
Transparency International reports highlight the link between corruption and inequality, creating a vicious circle of corruption, unequal distribution of power in society, and unequal distribution of wealth. (Transparency International, 2017)

Considering that wealthy countries can allocate more resources to put in place preventive measures and, in general, to the anti-corruption systems, we have analyzed the corruption perception index against the level of country development, i.e. Gross Domestic Product (GDP) per capita. Chart no. 1 highlights the perceptions of corruption (CPI) per capita GDP, at the level of sample countries in the analysis, on all continents of the globe according to table no. 1. As we can see, there is a close link between the level of development and the perception of corruption.

Chart no. 1 - Evolution of the Global Perceptions of Corruption Index in relation to GDP per capita

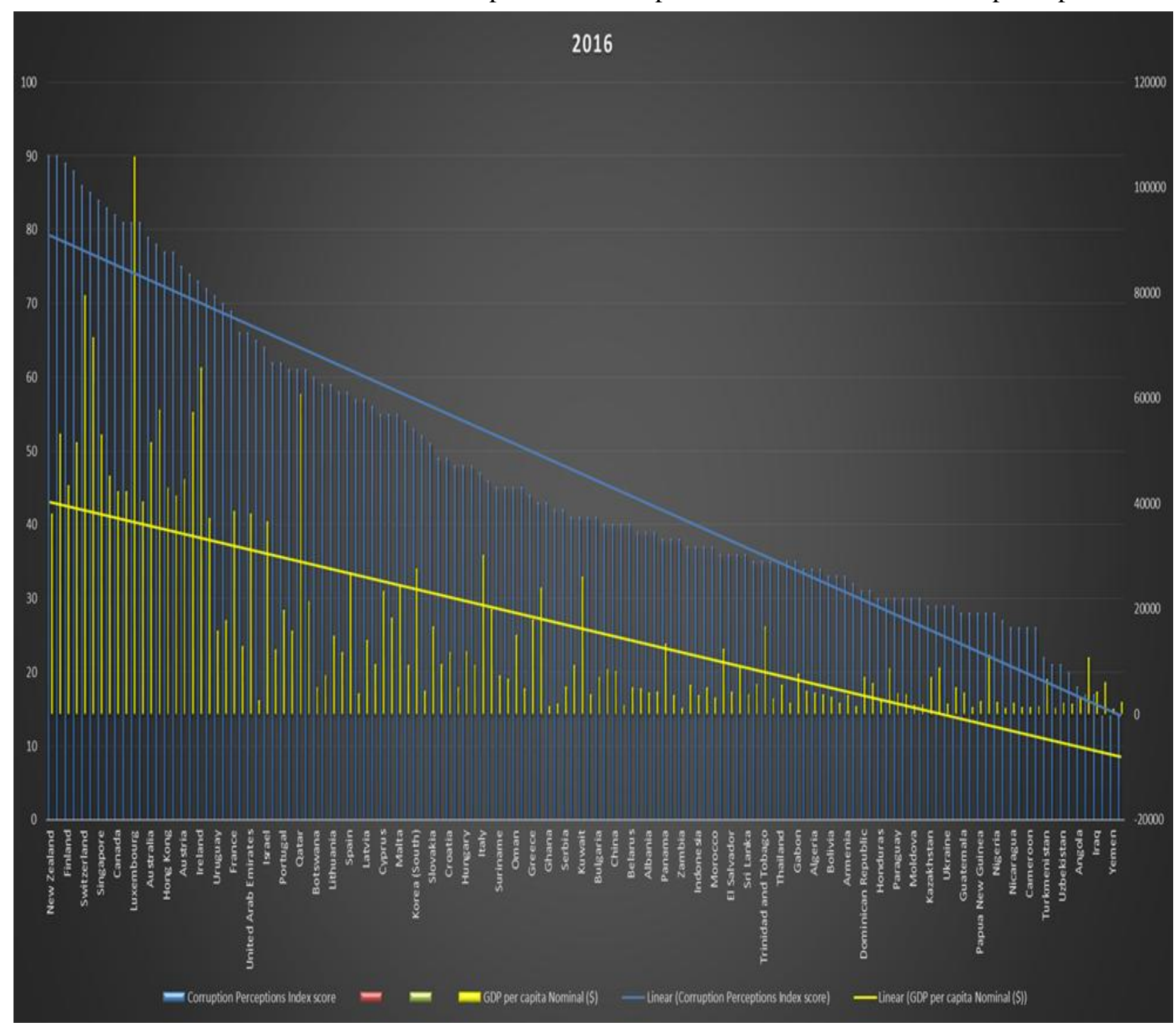

Chart no. 1- made by authors, data source World Bank, Transparency International 
Table no. 1: Countries in CPI vs. GDP analysis

\begin{tabular}{|c|c|c|c|c|c|c|c|c|c|c|c|c|c|c|c|c|c|}
\hline $\begin{array}{l}\hat{b} \\
\vdots \\
\vdots \\
j\end{array}$ & 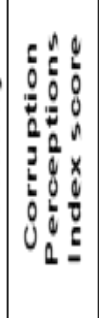 & 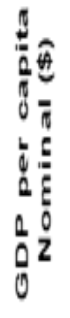 & $\mid \begin{array}{l} \\
\vdots \\
u \\
\vdots \\
\mathbf{z}\end{array}$ & 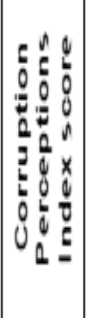 & 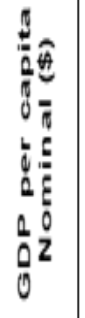 & $\begin{array}{l}\lambda \\
\vdots \\
0 \\
0 \\
\vdots\end{array}$ & 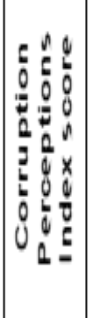 & 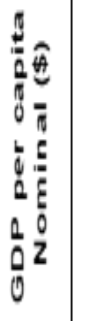 & $\begin{array}{l}\vdots \\
0 \\
\vdots \\
z\end{array}$ & 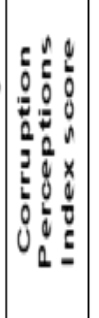 & 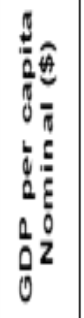 & $\begin{array}{l}\lambda \\
\vdots \\
\vdots \\
0 \\
0 \\
0\end{array}$ & 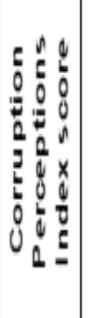 & 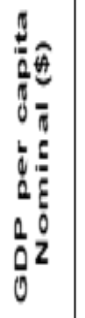 & $\begin{array}{l}5 \\
0 \\
\vdots \\
2\end{array}$ & 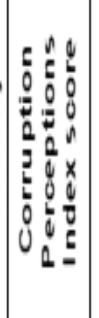 & 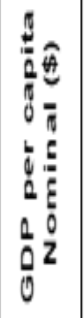 \\
\hline $1 \mid$ New Zarale & 90 & 30060 & 26) Bhutan & 66 & 2025 & 51| Hungaly & 48 & 11903 & 76 | Mongolia & 38 & 3704 & 101| Honduras & 30 & 2551 & 128]//enezula & 17 & 10755 \\
\hline 2 Denmalk & 9 & 53243 & 27 |srael & 64 & 36557 & 52 Romania & 48 & 9439 & 77 Zambia & 38 & 1231 & 102 Nexico & 30 & 8609 & 127 Ian & 17 & 4334 \\
\hline 3 Finland & 89 & 43492 & 28 Poland & 62 & 1230 & $53 \mid$ taly & 47 & 30294 & 78 Colonbia & 37 & 5023 & 103 Parayay & 30 & 3908 & 128) Libya & 14 & 6609 \\
\hline 45 weden & 88 & 51004 & 29) Portugal & 62 & 19750 & $54 \mid$ Savoid Arate & 46 & 19922 & 79 Indonesia & 37 & 36250 & 104 Azerctaijan & 30 & 3759 & 120) Yemen & 14 & 1075 \\
\hline 5) Switzerlan & 86 & 79578 & 30 Bartodos & 61 & 15955 & \begin{tabular}{|c|l|}
55 & Sunname \\
\end{tabular} & 45 & 7347 & $80 \mid$ The FYRo & 37 & 5060 & 105 Nolbova & 30 & 1872 & 130) Sudan & 14 & 2381 \\
\hline 6) Nonay & 85 & 71497 & 31 Qatar & 61 & 60733 & 56 |lontenen| & 45 & 6800 & 81 |llorocos & 37 & 3101 & \begin{tabular}{|l|l|l|l|l|l|l}
106 & \\
\end{tabular} & 30 & 1998 & & & \\
\hline 7 Singapore & 84 & 53253 & 32 Shovenia & 61 & 21370 & 57 Oman & 45 & 150000 & 82. Argentina & 36 & 12425 & 107 Kazakhsita & 20 & 7138 & & & \\
\hline 8 Netherland & 83 & 45210 & 33) Botwwana & 60 & 5082 & 58 South Afich & 45. & 5018 & 83. El Sal ladd & 36 & 4330 & 108 Russia & 20 & 8838 & & & \\
\hline 9.Canada & 82 & 42319 & 34dDominica & 50 & 7412 & 50 Greeces & 44 & 18078 & 84 |Wadives & 36 & 9247 & 109/ Ukraine & 20 & 2052 & & & \\
\hline 10 Germany & 81 & 42326 & 35 Lithuania & 50 & 14809 & 60 Banrain & 43 & 24119 & 85: Sri Lanka & 36 & 3870 & 110 |ran & 20 & 5124 & & & \\
\hline 11 Luxembou & 81 & 105820 & 36/Costa Rice & 58 & 11749 & 61) Ghana & 43 & 1551 & $86 \mathrm{Pen}$ & 35 & 572 & 111 Guatemala & 28 & 4102 & & & \\
\hline 12 United Kin & 81 & 40412 & 37/ Spain & 58 & 27012 & 62 (Solomon & 42 & 2028 & 87 Trindad ad & 35 & 16717 & \begin{tabular}{|l|l|}
$112 \mid$ |lyammar \\
\end{tabular} & 28 & 1307 & & & \\
\hline 13. Australia & 79 & 51593 & 38 Gevgia & 57 & 3908 & 63. 5 Serbia & 42 & 5224 & 880 Philipoines & 35 & 2991 & 113: Papua Ne: & 28 & 2517 & & & \\
\hline 14 loseand & 78 & 57809 & 39. Lativa & 57 & 14141 & \begin{tabular}{|l|l|}
64 & Tukney \\
\end{tabular} & 41 & 9317 & 89) Thalland & 35 & 5662 & 114|_ebanon & 28 & 11271 & & & \\
\hline 15 Hong Kond & 77 & 42663 & 40) Grenada & 50 & 9600 & 65 Kunat & 41 & 26140 & 90) Timor-Lest & 35 & 2104 & 115. Nigena & 28 & 2200 & & & \\
\hline 16 Begium & 77 & 41491 & 41 Cypous & 55 & 23425 & 66) Tunisia & 41 & 3777 & 91 Gabon & 35 & 7741 & 116: Mauritania & 27 & 1244 & & & \\
\hline 17 Austria & 75 & 4460 & $42($ Czech Pear & 56 & 18326 & 67 Bugana & 41 & 7091 & 92 Gujana & 34 & 4492 & 117 /Nicangua & 26 & 2115 & & & \\
\hline 18The Uhited & 74 & 57294 & 4.3. alla & 55 & 24228 & 68 Brazil & 40) & 8587 & 93) Algeria & 34 & 4122 & \begin{tabular}{|l|l|}
18 & Banglades \\
\end{tabular} & 26 & 1404 & & & \\
\hline 19. reland & 73 & 66871 & 44|l| aurtius & 54 & 9322 & 69) China & 40) & 8266 & 94 Egypt & 34 & 3006 & 119. Cameroon & 26 & 1303 & & & \\
\hline 20) Japan & 72 & 37304 & 45) Korea (So & 53 & 27633 & 70 |ndia & 40) & 1719 & $95:$ Boliva & 33 & 3276 & 120) Kenja & 26 & 1522 & & & \\
\hline 21 Uroguay & 71 & 158604 & 46/ Namibia & 52 & 4428 & 71 Belans & 40 & 5092 & 960 Vietnam & 33 & 2164 & \begin{tabular}{|l|l|}
121 & Tukmenis \\
\end{tabular} & 22 & 6694 & & & \\
\hline 22 Estonia & 70 & 17808 & 47/Shorkia & 51 & 16648 & 72 lamaica & 39 & 4870 & 97/Amenia & 33 & 3506 & 122 Canbodia & 21 & 1228 & & & \\
\hline 23) Frances & 60 & 38537 & 48/Malaysia & 40. & 9546 & 73. Albania & 39 & 4210 & 98 Pakistan & 32 & 1474 & 123 Uzzekistal & 21 & 2131 & & & \\
\hline 24 Chile & 66 & 12910 & 49. Croatia & 49. & 11858 & 74 Bosnia an & 39 & 4280 & 99 Cominican & 31 & 7083 & \begin{tabular}{|l|l|}
124 Republico \\
\end{tabular} & 20 & 1981 & & & \\
\hline 25. United $\mathrm{Arab}$ & 60 & 30050 & 50) Jordan & 48] & 502 & 75 Parama & 38 & 13515 & 100) Ecuador & 31 & 5997 & 125. Angola & 18) & 3300 & & & \\
\hline
\end{tabular}

Reporting the corruption perception index to the population's poverty level is relevant. Poverty is often defined by economic standards based on income levels and access to basic human needs such as food, water and housing. Poverty is often described as ranging from extreme to moderate. The World Bank is the main source of global information on extreme poverty and sets the international poverty line. The poverty line was revised in 2015 since then, a person is considered to be in extreme poverty if he lives with less than $\$ 1.90$ per day. 
This measure of poverty is based on the monetary value of a person's daily consumption. (Roser and OrtizOspina, 2018) Taking into consideration the World Bank's ranking of countries, according to the percentage of their population, with an income less than $\$ 1.90$ purchasing power parity, and analyzing globally, according to chart no. 2 and 3 it can be seen that the Corruption Perceptions Index (CPI) decreases linearly as the poverty level increases.

Chart no. 2 - Indicators of corruption perception in relation to the population's poverty level

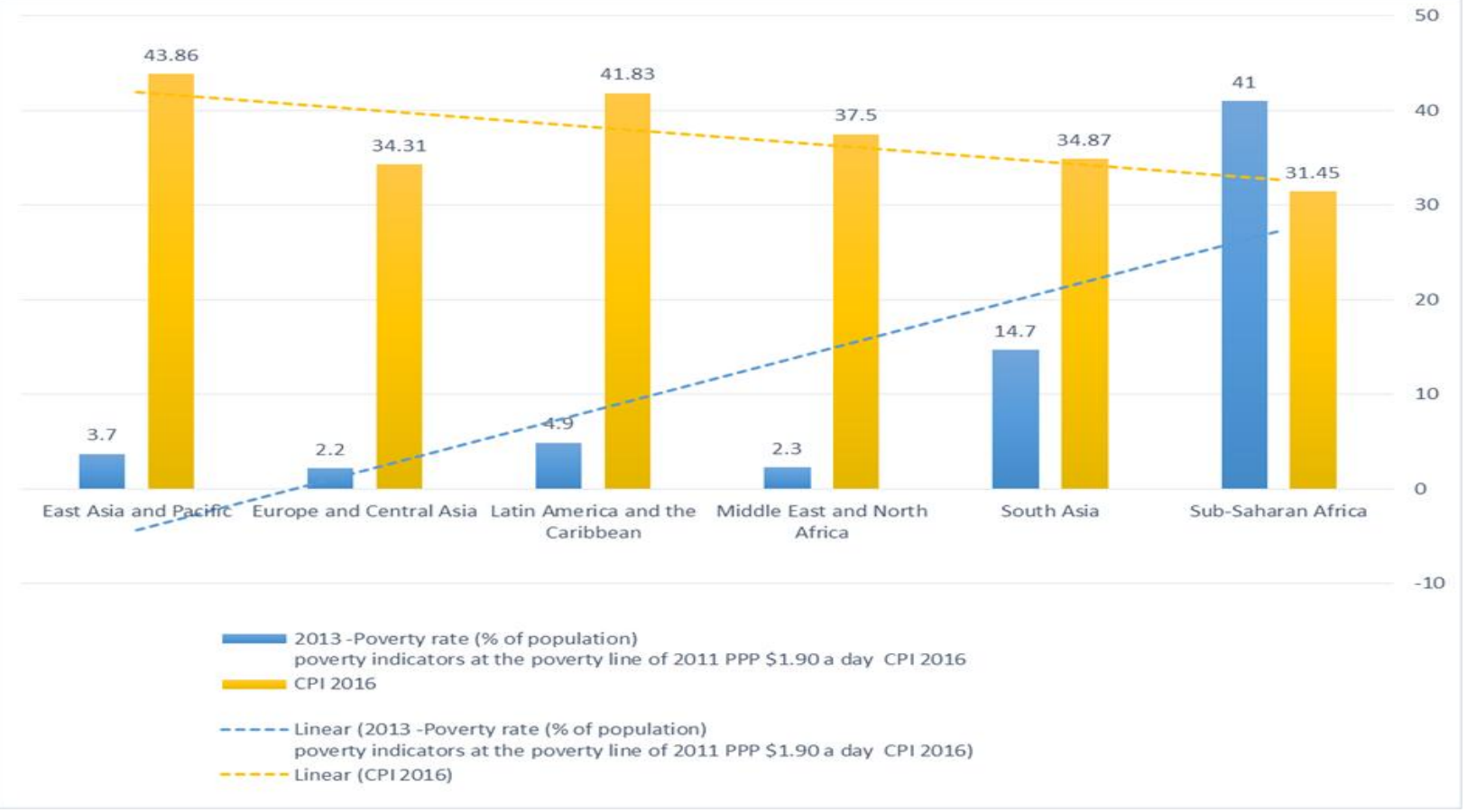

Chart no. 2 made by the authors, data source World Bank, Transparency International

Chart no. 3 - Corruption Perceptions Index in relation with the Extreme Poverty Indicator (Percentage of population living with less than 1.90 USD per day)

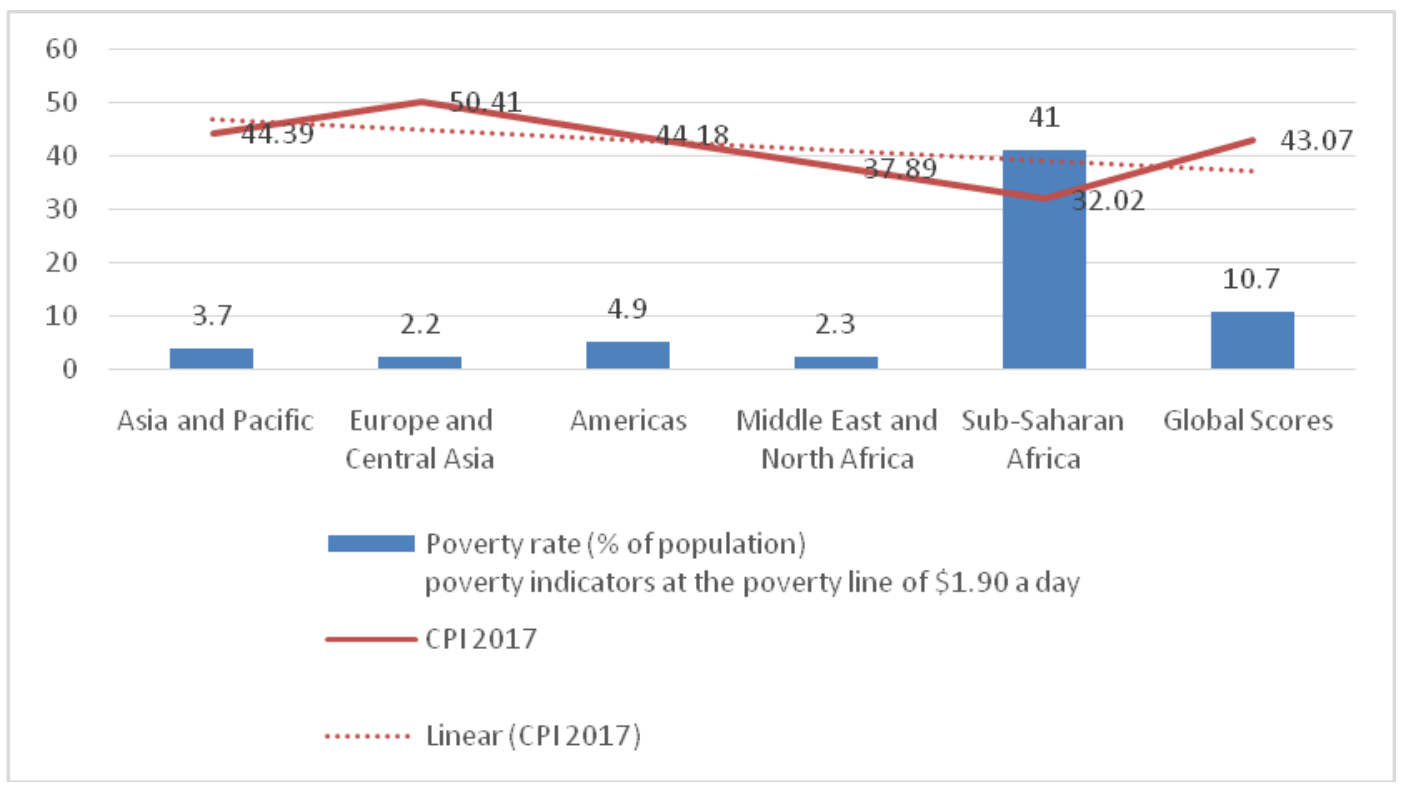

Chart no. 3 made by the authors, data source World Bank, Transparency International

The rankings describing the global corruption situation, the analysis made in the present paper (graphs 2 and 3 above), reporting the CPI to gross domestic product per capita (GDP), the population poverty level and the indicator of inequality indicates a higher degree of corruption in poor countries and a lower degree in rich ones. 


\section{Conclusions}

Studies and polls conducted to quantify corruption perception increase corruption awareness and create the necessary premises to combat this scourge. Also, tools for assessing the effectiveness of the fight against corruption as well as the methods used in this respect are created.

Transparency International reports show that, despite attempts to combat global corruption, most countries are developing very slowly in this respect. Reducing corruption is a lengthy process, but in recent years many countries have progressed very little or not at all, with CPI scores improving significantly in just a few states, including Côte d'Ivoire, Senegal and the United Kingdom, while worsening in other countries, such as Syria, Yemen and Australia.

As shown in the annex table no. 1, New Zealand and Denmark are in the top rankings in 2017 also, with a score of 89 and 88, respectively. Syria, South Sudan and Somalia are ranked 14, 12 and 9 points, respectively. The region with the best results is Western Europe, with an average score of 66 points. The regions with the weakest results are Sub-Saharan Africa (average score 32), Eastern Europe and Central Asia (average score 34). (Transparency International, 2017)

As can be easily seen in chart no. 4, and as follows from the data listed in the annex no. 1, the only countries in the world that consistently achieve a score close to the maximum of 100 points in each of the 7 years under review are New Zealand and Denmark. On the opposite side, the most corrupt countries in the world are North Korea, Somalia and Afghanistan.

\section{Chart no. 4 - Global Perceptions of Corruption Index}

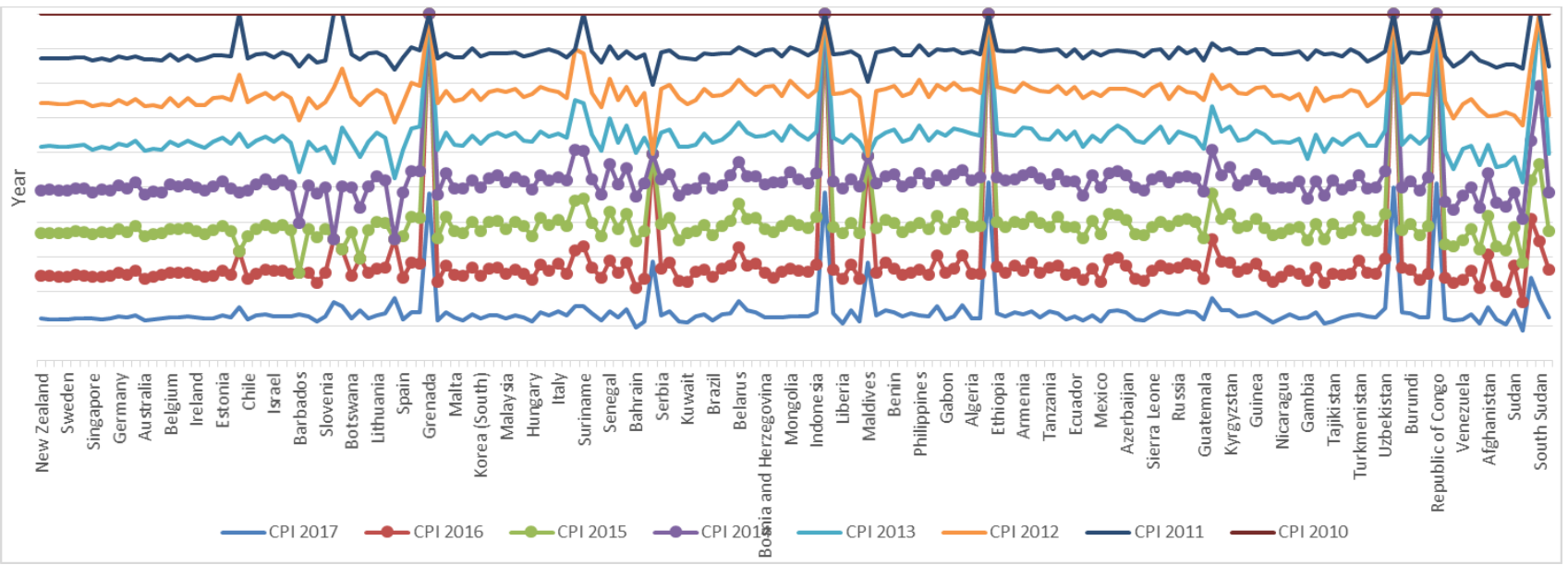

Chart no. 4 - made by the authors, Transparency International data source - CPI evolution, Transparency International - CPI 2017

Overall, there are no significant changes in the Corruption Perceptions Index in 2017. Stagnation does not indicate that the fight against corruption has improved, but rather the opposite, not even New Zealand having scored the perfect score of 100 points in recent years. Only a few countries are showing small incremental changes indicating signs of improvement among the world's states with scores over 80 points: New Zealand (89), Denmark (88),Finland, Norway, Switzerland (85 points each), Singapore, Sweden (84 points each), Canada Netherlands Luxembourg and the United Kingdom, each with 82 points and Germany with 81 points. Countries in northern Europe are considered to be the least corrupt, but specialists foresee the possibility that they may experience an increase in acts conflicting with moral norms, thus confirming the theories that corruption affects all states of the world and reinforcing arguments in favor of identifying effective means to control and maintain this phenomenon as low as possible.

As it can be seen, countries with good scores on Corruption Perceptions Index (i.e. countries considered less corrupt) tend to have good indicators related to the Gross Domestic Product as a measure of development level, as well as good indicators when it comes to measuring population poverty and inequality. In the analysis of corruption inequality is important and needs to be addressed, as it slows down the reduction of poverty. Combating and limiting inequality leads to poverty reduction, generating economic growth. 
Addressing inequality is an important means of combating absolute poverty, with the World Bank providing data on income inequality for most countries in the world. A common measure of inequality is the GINI index, whereby the World Bank measures annually the extent to which the distribution of income (or, in some cases, consumption expenditure) between individuals or households in an economy deviates from a fairly equal distribution. In the World Bank data, the index varies from 0 to 100: a country with a total revenue distribution, where each person received the same income, would have a GINI of 0; a country with a completely uneven distribution, where a person has earned all the money, and everyone else has earned nothing, would have an index of 100. Thus, a 0 GINI index represents perfect equality, while an index of 100 points to major inequality.

As can be seen from Chart no. 4, the link between corruption and inequality is evident globally; there is a vicious circle between corruption, the unequal distribution of power in society and the unequal distribution of wealth.

By comparing CPI 2017 with the GINI, in order to establish the interdependence relationships between them, one can see a correspondence of the changes recorded by the corruption perception index in relation to the GINI indicator, the two indicators being in an obvious interdependence. We used the graphical method to compare the two sets of values representing the GINI and the CPI 2017 corruption perception index, respectively, to establish the link between them, as shown in the graphic no. 5 down below.

\section{Graphic no. 5- Global Perceptions of Corruption Percentage reported to the inequality coefficient GINI}

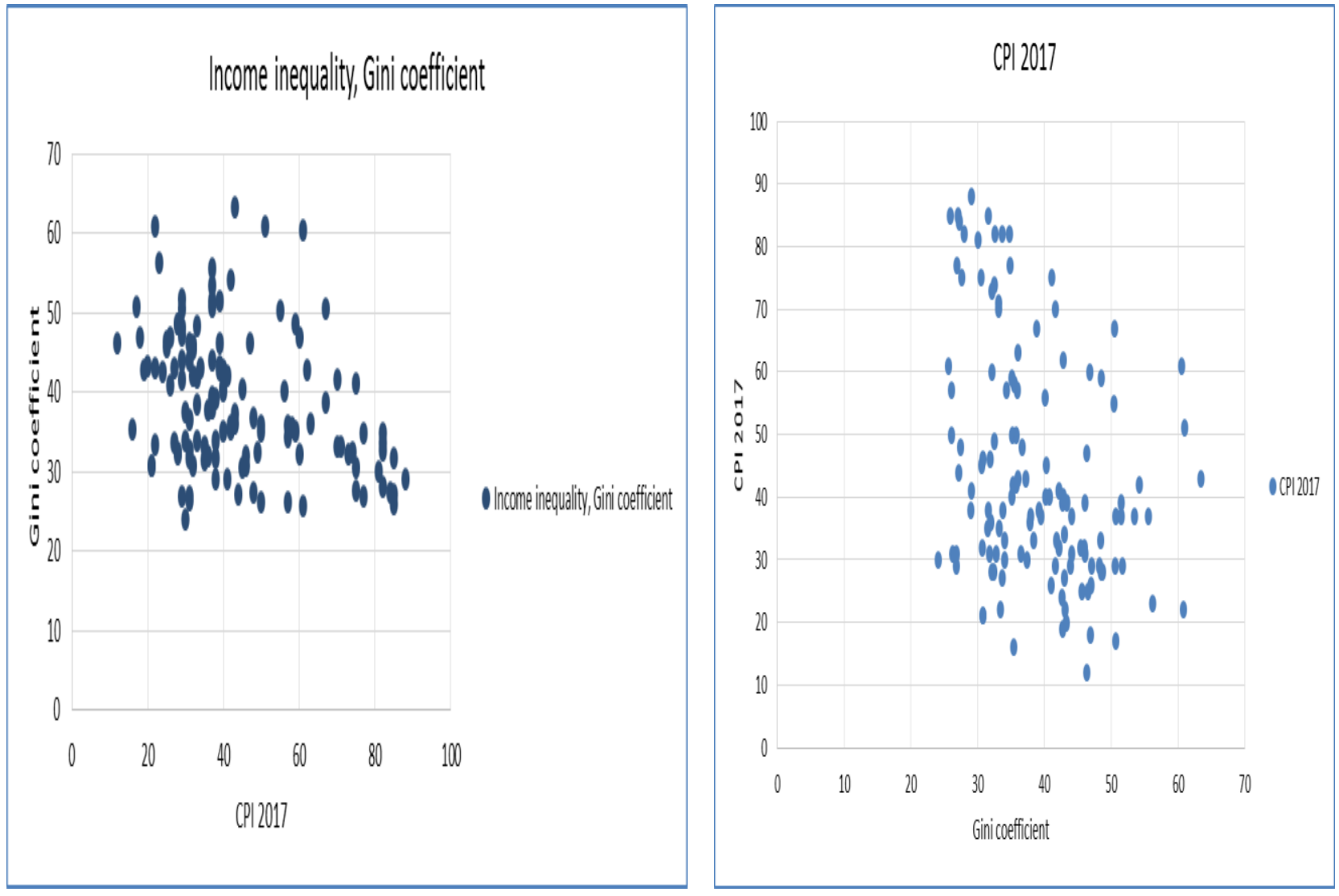

Graphic no. 5 made by authors, data source World Bank, Transparency International

As it results from this paper (Graphs 1 and 2 above), it is worth noting that the corruption perception index has a favorable trend depending on the evolution of the gross domestic product. Also, from Chart 6 below, we can see that there is a close link between the Corruption Perceptions Index and the population's poverty level, expressed as the percentage of the population in a country with a less than 1.90 USD income.

Chart no. 6 - Corruption perception index against the poverty level of the population 


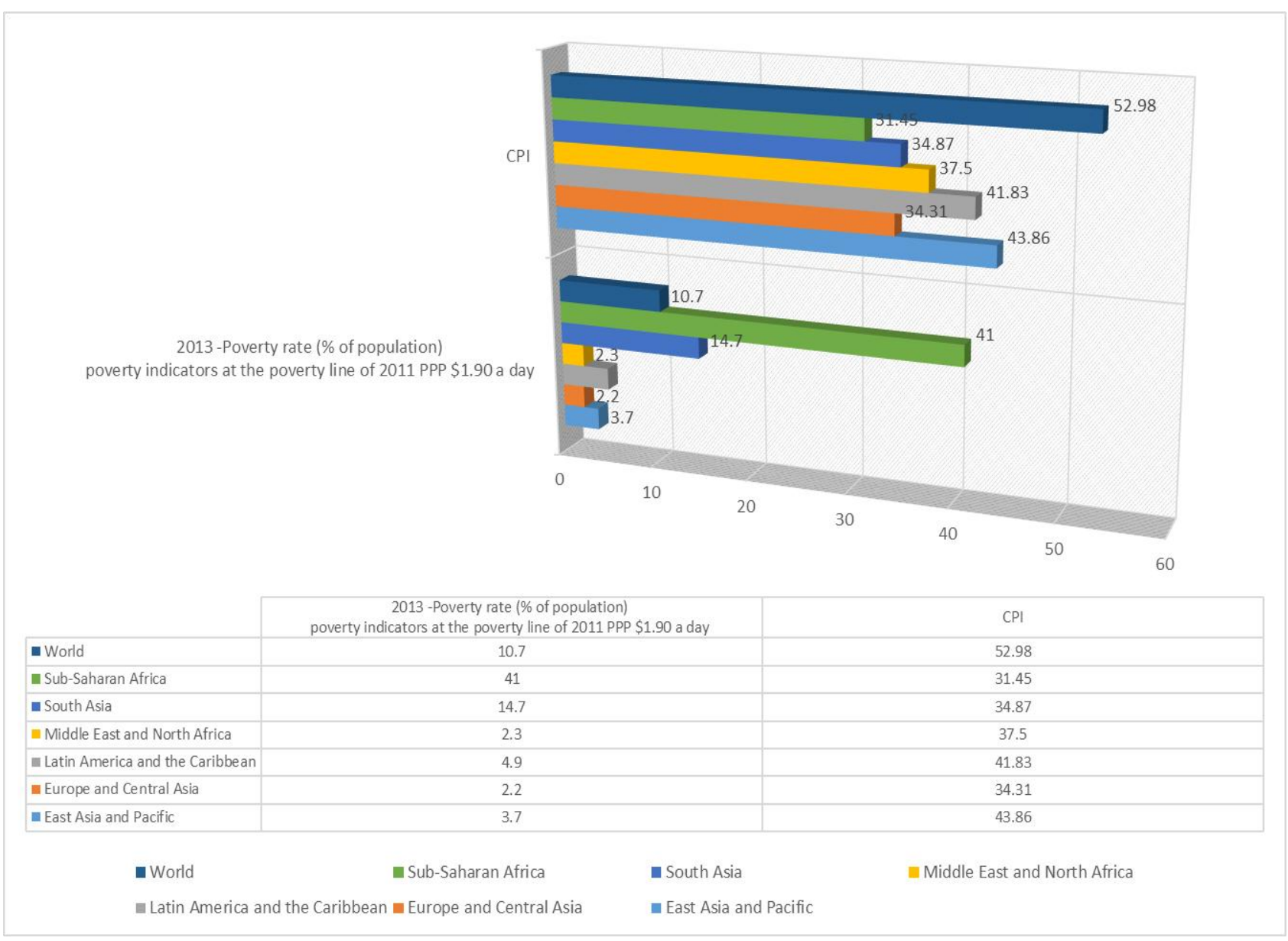

Chart no. 6 conducted by authors, data source World Bank, Transparency International

The results of this analysis reveal a close link between Corruption Perceptions Index, Global Poverty Level and GINI, confirming the hypothesis that they are stronger corruption predictors than the gross domestic product per capita.

\section{Bibliography}

ComisiaEuropeana, Raportanticoruptie al UE- Eurostat 2010

Michael, J., „Syndromes of Corruption: Wealth, Power, and Democracy”, EdituraPolirom, 2007

Riggs, F., „Coups and Crashes: Lessons for Public Administration”, înFarazmand,A. (editor), Modern Systems of Government. Exploring the Role of Bureaucrats and Politicians, Thousand Oaks, CL: Sage Publications, 1997

Friedrich, C.J., „Corruption Cases in Historical Perspective”, înHeidenheimer,A.J., Johnston, M. şiLeVine, V.T. (editori), Political Corruption. A Handbook, New Brunswick, NJ: Transaction Publishers, 1999

Max Roser and Esteban Ortiz-Ospina (2018) - "Global Extreme Poverty". Published online at OurWorldInData.org. Retrieved from: 'https://ourworldindata.org/extreme-poverty'

Nye, J.S., „Corruption and Political Development: A Cost-Benefit Analysis”, 1961, The American Political Science Review, vol. 61, nr. 2, pp. 417-427

Radu, L. și Gulyas, G., (26)/2010, Coruptia in Romania, o problema de nerezolvatRevistaTransilvană de Ştiinţe Administrative 2 (26)/2010, pp. 107-124

Transparency International, 2017, [Online] available at www.transparency.org/cpi2017

Proiect INSERT - împreunăpentru o societate inclusive 2014 [Online] available athttp://societate-inclusiva.ro/wp content/uploads/2014/11/pliante_promovare_incluziune/pliant\%20incluziune\%20sociala\%20Europa.pdf -accessed on April 24 $4^{\text {th }}, 2017$ 


\section{Anexanr. 1}

\begin{tabular}{|c|c|c|c|c|c|c|c|c|}
\hline Country & $\begin{array}{c}2017 \\
\text { CPI } \\
\text { Score }\end{array}$ & $\begin{array}{c}2016 \\
\text { CPI } \\
\text { Score }\end{array}$ & \begin{tabular}{|l}
2015 \\
CPI \\
Score
\end{tabular} & $\begin{array}{c}2014 \\
\text { CPI } \\
\text { Score }\end{array}$ & $\begin{array}{c}2013 \\
\text { CPI } \\
\text { Score }\end{array}$ & $\begin{array}{c}2012 \\
\text { CPI } \\
\text { Score }\end{array}$ & Region & $\begin{array}{c}\text { Income } \\
\text { inequality, } \\
\text { Gini } \\
\text { coefficient }\end{array}$ \\
\hline Canada & 82 & 82 & 83 & 81 & 81 & 84 & Americas & 33.7 \\
\hline United States & 75 & 74 & 76 & 74 & 73 & 73 & Americas & 41.1 \\
\hline Uruguay & 70 & 71 & 74 & 73 & 73 & 72 & Americas & 41.6 \\
\hline Barbados & 68 & 61 & N/A & 74 & 75 & 76 & Americas & \\
\hline Chile & 67 & 66 & 70 & 73 & 71 & 72 & Americas & 50.5 \\
\hline Bahamas & 65 & 66 & N/A & 71 & 71 & 71 & Americas & \\
\hline Costa Rica & 59 & 58 & 55 & 54 & 53 & 54 & Americas & 48.5 \\
\hline $\begin{array}{l}\text { Saint Vincent and the } \\
\text { Grenadines }\end{array}$ & 58 & 60 & N/A & 62 & 62 & 62 & Americas & $\mathrm{n} / \mathrm{a}$ \\
\hline Dominica & 57 & 59 & N/A & 58 & 58 & 58 & Americas & $\mathrm{n} / \mathrm{a}$ \\
\hline Saint Lucia & 55 & 60 & N/A & 71 & 71 & 71 & Americas & $\mathrm{n} / \mathrm{a}$ \\
\hline Grenada & 52 & 56 & N/A & N/A & N/A & N/A & Americas & $\mathrm{n} / \mathrm{a}$ \\
\hline Cuba & 47 & 47 & 47 & 46 & 46 & 48 & Americas & $\mathrm{n} / \mathrm{a}$ \\
\hline Jamaica & 44 & 39 & 41 & 38 & 38 & 38 & Americas & $\mathrm{n} / \mathrm{a}$ \\
\hline Suriname & 41 & 45 & 36 & 36 & 36 & 37 & Americas & $\mathrm{n} / \mathrm{a}$ \\
\hline Trinidad and Tobago & 41 & 35 & 39 & 38 & 38 & 39 & Americas & $\mathrm{n} / \mathrm{a}$ \\
\hline Argentina & 39 & 36 & 32 & 34 & 34 & 35 & Americas & 42.7 \\
\hline Guyana & 38 & 34 & 29 & 30 & 27 & 28 & Americas & $\mathrm{n} / \mathrm{a}$ \\
\hline Brazil & 37 & 40 & 38 & 43 & 42 & 43 & Americas & 51.5 \\
\hline Colombia & 37 & 37 & 37 & 37 & 36 & 36 & Americas & 53.5 \\
\hline Panama & 37 & 38 & 39 & 37 & 35 & 38 & Americas & 50.70 \\
\hline Peru & 37 & 35 & 36 & 38 & 38 & 38 & Americas & 44.1 \\
\hline Bolivia & 33 & 33 & 34 & 35 & 34 & 34 & Americas & 48.4 \\
\hline El Salvador & 33 & 36 & 39 & 39 & 38 & 38 & Americas & 41.8 \\
\hline Ecuador & 32 & 31 & 32 & 33 & 35 & 32 & Americas & 45.4 \\
\hline Dominican Republic & 29 & 31 & 33 & 32 & 29 & 32 & Americas & 47.1 \\
\hline Honduras & 29 & 30 & 31 & 29 & 26 & 28 & Americas & 50.6 \\
\hline Mexico & 29 & 30 & 31 & 35 & 34 & 34 & Americas & 48.2 \\
\hline Paraguay & 29 & 30 & 27 & 24 & 24 & 25 & Americas & 51.7 \\
\hline Guatemala & 28 & 28 & 28 & 32 & 29 & 33 & Americas & 48.7 \\
\hline Nicaragua & 26 & 26 & 27 & 28 & 28 & 29 & Americas & 47.00 \\
\hline Haiti & 22 & 20 & 17 & 19 & 19 & 19 & Americas & 60.8 \\
\hline Venezuela & 18 & 17 & 17 & 19 & 20 & 19 & Americas & 46.9 \\
\hline Average Americas & 44.19 & 44.09 & 40.31 & 44.94 & 44.32 & 45.03 & & 42.64 \\
\hline New Zealand & 89 & 90 & 91 & 91 & 91 & 90 & Asia Pacific & $\mathrm{n} / \mathrm{a}$ \\
\hline Singapore & 84 & 84 & 85 & 84 & 86 & 87 & Asia Pacific & $\mathrm{n} / \mathrm{a}$ \\
\hline Australia & 77 & 79 & 79 & 80 & 81 & 85 & Asia Pacific & 34.9 \\
\hline Hong Kong & 77 & 77 & 75 & 74 & 75 & 77 & Asia Pacific & $\mathrm{n} / \mathrm{a}$ \\
\hline Japan & 73 & 72 & 75 & 76 & 74 & 74 & Asia Pacific & 32.1 \\
\hline Bhutan & 67 & 65 & 65 & 65 & 63 & 63 & Asia Pacific & 38.8 \\
\hline Taiwan & 63 & 61 & 62 & 61 & 61 & 61 & Asia Pacific & $\mathrm{n} / \mathrm{a}$ \\
\hline Brunei Darussalam & 62 & 58 & N/A & N/A & 60 & 55 & Asia Pacific & $\mathrm{n} / \mathrm{a}$ \\
\hline Korea, South & 54 & 53 & 54 & 55 & 55 & 56 & Asia Pacific & $\mathrm{n} / \mathrm{a}$ \\
\hline Malaysia & 47 & 49 & 50 & 52 & 50 & 49 & Asia Pacific & 46.30 \\
\hline Vanuatu & 43 & N/A & N/A & N/A & N/A & N/A & Asia Pacific & 37.2 \\
\hline China & 41 & 40 & 37 & 36 & 40 & 39 & Asia Pacific & 42.2 \\
\hline India & 40 & 40 & 38 & 38 & 36 & 36 & Asia Pacific & 35.1 \\
\hline Solomon Islands & 39 & 42 & N/A & N/A & N/A & N/A & Asia Pacific & 46.1 \\
\hline Sri Lanka & 38 & 36 & 37 & 38 & 37 & 40 & Asia Pacific & 39.2 \\
\hline Timor-Leste & 38 & 35 & 28 & 28 & 30 & 33 & Asia Pacific & 31.6 \\
\hline Indonesia & 37 & 37 & 36 & 34 & 32 & 32 & Asia Pacific & 39.5 \\
\hline Thailand & 37 & 35 & 38 & 38 & 35 & 37 & Asia Pacific & 37.9 \\
\hline Mongolia & 36 & 38 & 39 & 39 & 38 & 36 & Asia Pacific & 32 \\
\hline Vietnam & 35 & 33 & 31 & 31 & 31 & 31 & Asia Pacific & $\mathrm{n} / \mathrm{a}$ \\
\hline Philippines & 34 & 35 & 35 & 38 & 36 & 34 & Asia Pacific & 43 \\
\hline Maldives & 33 & 36 & N/A & N/A & N/A & N/A & Asia Pacific & 38.4 \\
\hline Pakistan & 32 & 32 & 30 & 29 & 28 & 27 & Asia Pacific & 30.7 \\
\hline Nepal & 31 & 29 & 27 & 29 & 31 & 27 & Asia Pacific & 32.8 \\
\hline Myanmar & 30 & 28 & 22 & 21 & 21 & 15 & Asia Pacific & $\mathrm{n} / \mathrm{a}$ \\
\hline Lao PDR & 29 & 30 & 25 & 25 & 26 & 21 & Asia Pacific & $\mathrm{n} / \mathrm{a}$ \\
\hline Papua New Guinea & 29 & 28 & 25 & 25 & 25 & 25 & Asia Pacific & 43.9 \\
\hline 8 Bangladesh & 28 & 26 & 25 & 25 & 27 & 26 & Asia Pacific & 32.1 \\
\hline Cambodia & 21 & 21 & 21 & 21 & 20 & 22 & Asia Pacific & 30.8 \\
\hline Korea, North & 17 & 12 & 8 & 8 & 8 & 8 & Asia Pacific & $\mathrm{n} / \mathrm{a}$ \\
\hline
\end{tabular}




\begin{tabular}{|c|c|c|c|c|c|c|c|c|}
\hline Afghanistan & 15 & 15 & 11 & 12 & 8 & 8 & Asia Pacific & $\mathrm{n} / \mathrm{a}$ \\
\hline Average Asia Pacific & 44.39 & 43.87 & 42.56 & 42.70 & 43.04 & 42.64 & & 37.23 \\
\hline Denmark & 88 & 90 & 91 & 92 & 91 & 90 & Europe and Central Asia & 29.1 \\
\hline Finland & 85 & 89 & 90 & 89 & 89 & 90 & Europe and Central Asia & 27.1 \\
\hline Norway & 85 & 85 & 88 & 86 & 86 & 85 & Europe and Central Asia & 25.9 \\
\hline Switzerland & 85 & 86 & 86 & 86 & 85 & 86 & Europe and Central Asia & 31.6 \\
\hline Sweden & 84 & 88 & 89 & 87 & 89 & 88 & Europe and Central Asia & 27.3 \\
\hline Luxembourg & 82 & 81 & 85 & 82 & 80 & 80 & Europe and Central Asia & 34.80 \\
\hline Netherlands & 82 & 83 & 84 & 83 & 83 & 84 & Europe and Central Asia & 28 \\
\hline United Kingdom & 82 & 81 & 81 & 78 & 76 & 74 & Europe and Central Asia & 32.6 \\
\hline Germany & 81 & 81 & 81 & 79 & 78 & 79 & Europe and Central Asia & 30.1 \\
\hline Iceland & 77 & 78 & 79 & 79 & 78 & 82 & Europe and Central Asia & 26.9 \\
\hline Austria & 75 & 75 & 76 & 72 & 69 & 69 & Europe and Central Asia & 30.5 \\
\hline Belgium & 75 & 77 & 77 & 76 & 75 & 75 & Europe and Central Asia & 27.60 \\
\hline Ireland & 74 & 73 & 75 & 74 & 72 & 69 & Europe and Central Asia & 32.5 \\
\hline Estonia & 71 & 70 & 70 & 69 & 68 & 64 & Europe and Central Asia & 33.1 \\
\hline France & 70 & 69 & 70 & 69 & 71 & 71 & Europe and Central Asia & 33.1 \\
\hline Portugal & 63 & 62 & 64 & 63 & 62 & 63 & Europe and Central Asia & 36 \\
\hline Slovenia & 61 & 61 & 60 & 58 & 57 & 61 & Europe and Central Asia & 25.6 \\
\hline Poland & 60 & 62 & 63 & 61 & 60 & 58 & Europe and Central Asia & 32.10 \\
\hline Lithuania & 59 & 59 & 59 & 58 & 57 & 54 & Europe and Central Asia & 35.1 \\
\hline Latvia & 58 & 57 & 56 & 55 & 53 & 49 & Europe and Central Asia & 35.5 \\
\hline Cyprus & 57 & 55 & 61 & 63 & 63 & 66 & Europe and Central Asia & 34.3 \\
\hline Czech Republic & 57 & 55 & 56 & 51 & 48 & 49 & Europe and Central Asia & 26.1 \\
\hline Spain & 57 & 58 & 58 & 60 & 59 & 65 & Europe and Central Asia & 35.9 \\
\hline Georgia & 56 & 57 & 52 & 52 & 49 & 52 & Europe and Central Asia & 40.10 \\
\hline Malta & 56 & 55 & 60 & 55 & 56 & 57 & Europe and Central Asia & $\mathrm{n} / \mathrm{a}$ \\
\hline Italy & 50 & 47 & 44 & 43 & 43 & 42 & Europe and Central Asia & 35.2 \\
\hline Slovakia & 50 & 51 & 51 & 50 & 47 & 46 & Europe and Central Asia & 26.1 \\
\hline Croatia & 49 & 49 & 51 & 48 & 48 & 46 & Europe and Central Asia & 32.5 \\
\hline Greece & 48 & 44 & 46 & 43 & 40 & 36 & Europe and Central Asia & 36.7 \\
\hline Romania & 48 & 48 & 46 & 43 & 43 & 44 & Europe and Central Asia & 27.40 \\
\hline Montenegro & 46 & 45 & 44 & 42 & 44 & 41 & Europe and Central Asia & 31.9 \\
\hline Hungary & 45 & 48 & 51 & 54 & 54 & 55 & Europe and Central Asia & 30.6 \\
\hline Belarus & 44 & 40 & 32 & 31 & 29 & 31 & Europe and Central Asia & 27.2 \\
\hline Bulgaria & 43 & 41 & 41 & 43 & 41 & 41 & Europe and Central Asia & 36 \\
\hline Serbia & 41 & 42 & 40 & 41 & 42 & 39 & Europe and Central Asia & 29.1 \\
\hline Turkey & 40 & 41 & 42 & 45 & 50 & 49 & Europe and Central Asia & 40.20 \\
\hline Kosovo & 39 & 36 & 33 & 33 & 33 & 34 & Europe and Central Asia & $\mathrm{n} / \mathrm{a}$ \\
\hline Albania & 38 & 39 & 36 & 33 & 31 & 33 & Europe and Central Asia & 29 \\
\hline Bosnia and Herzegovina & 38 & 39 & 38 & 39 & 42 & 42 & Europe and Central Asia & 33.8 \\
\hline Armenia & 35 & 33 & 35 & 37 & 36 & 34 & Europe and Central Asia & 31.5 \\
\hline The FYR of Macedonia & 35 & 37 & 42 & 45 & 44 & 43 & Europe and Central Asia & $\mathrm{n} / \mathrm{a}$ \\
\hline Azerbaijan & 31 & 30 & 29 & 29 & 28 & 27 & Europe and Central Asia & 31.80 \\
\hline Kazakhstan & 31 & 29 & 28 & 29 & 26 & 28 & Europe and Central Asia & 26.3 \\
\hline Moldova & 31 & 30 & 33 & 35 & 35 & 36 & Europe and Central Asia & 26.8 \\
\hline Ukraine & 30 & 29 & 27 & 26 & 25 & 26 & Europe and Central Asia & 24.1 \\
\hline Kyrgyzstan & 29 & 28 & 28 & 27 & 24 & 24 & Europe and Central Asia & 26.8 \\
\hline Russia & 29 & 29 & 29 & 27 & 28 & 28 & Europe and Central Asia & 41.6 \\
\hline Uzbekistan & 22 & 21 & 19 & 18 & 17 & 17 & Europe and Central Asia & $\mathrm{n} / \mathrm{a}$ \\
\hline Tajikistan & 21 & 25 & 26 & 23 & 22 & 22 & Europe and Central Asia & 30.8 \\
\hline Turkmenistan & 19 & 22 & 18 & 17 & 17 & 17 & Europe and Central Asia & $\mathrm{n} / \mathrm{a}$ \\
\hline $\begin{array}{l}\text { Average Europe and } \\
\text { Central Asia }\end{array}$ & 54.24 & 54.2 & 54.4 & 53.56 & 52.86 & 52.82 & & 31.25 \\
\hline United Arab Emirates & 71 & 66 & 70 & 70 & 69 & 68 & Middle East and North Africa & $\mathrm{n} / \mathrm{a}$ \\
\hline Qatar & 63 & 61 & 71 & 69 & 68 & 68 & Middle East and North Africa & $\mathrm{n} / \mathrm{a}$ \\
\hline Israel & 62 & 64 & 61 & 60 & 61 & 60 & Middle East and North Africa & 42.8 \\
\hline Saudi Arabia & 49 & 46 & 52 & 49 & 46 & 44 & Middle East and North Africa & $\mathrm{n} / \mathrm{a}$ \\
\hline Jordan & 48 & 48 & 53 & 49 & 45 & 48 & Middle East and North Africa & $\mathrm{n} / \mathrm{a}$ \\
\hline Oman & 44 & 45 & 45 & 45 & 47 & 47 & Middle East and North Africa & $\mathrm{n} / \mathrm{a}$ \\
\hline Tunisia & 42 & 41 & 38 & 40 & 41 & 41 & Middle East and North Africa & 35.8 \\
\hline Morocco & 40 & 37 & 36 & 39 & 37 & 37 & Middle East and North Africa & 40.7 \\
\hline Kuwait & 39 & 41 & 49 & 44 & 43 & 44 & Middle East and North Africa & $\mathrm{n} / \mathrm{a}$ \\
\hline Bahrain & 36 & 43 & 51 & 49 & 48 & 51 & Middle East and North Africa & $\mathrm{n} / \mathrm{a}$ \\
\hline Algeria & 33 & 34 & 36 & 36 & 36 & 34 & Middle East and North Africa & $\mathrm{n} / \mathrm{a}$ \\
\hline Egypt & 32 & 34 & 36 & 37 & 32 & 32 & Middle East and North Africa & $\mathrm{n} / \mathrm{a}$ \\
\hline Iran & 30 & 29 & 27 & 27 & 25 & 28 & Middle East and North Africa & 37.4 \\
\hline Lebanon & 28 & 28 & 28 & 27 & 28 & 30 & Middle East and North Africa & $\mathrm{n} / \mathrm{a}$ \\
\hline Mauritania & 28 & 27 & 31 & 30 & 30 & 31 & Middle East and North Africa & 32.4 \\
\hline Iraq & 18 & 17 & 16 & 16 & 16 & 18 & Middle East and North Africa & $\mathrm{n} / \mathrm{a}$ \\
\hline
\end{tabular}




\begin{tabular}{|c|c|c|c|c|c|c|c|c|}
\hline Libya & 17 & 14 & 16 & 18 & 15 & 21 & Middle East and North Africa & $\mathrm{n} / \mathrm{a}$ \\
\hline Sudan & 16 & 14 & 12 & 11 & 11 & 13 & Middle East and North Africa & 35.40 \\
\hline Yemen & 16 & 14 & 18 & 19 & 18 & 23 & Middle East and North Africa & $\mathrm{n} / \mathrm{a}$ \\
\hline Syria & 14 & 13 & 18 & 20 & 17 & 26 & Middle East and North Africa & $\mathrm{n} / \mathrm{a}$ \\
\hline $\begin{array}{l}\text { Average Middle East and } \\
\text { North Africa }\end{array}$ & 36.30 & 35.80 & 38.20 & 37.75 & 36.65 & 38.20 & & 37.42 \\
\hline Botswana & 61 & 60 & 63 & 63 & 64 & 65 & Sub Saharan Africa & 60.5 \\
\hline Seychelles & 60 & N/A & N/A & N/A & N/A & N/A & Sub Saharan Africa & 46.8 \\
\hline Cape Verde & 55 & 59 & 55 & 57 & 58 & 60 & Sub Saharan Africa & $\mathrm{n} / \mathrm{a}$ \\
\hline Rwanda & 55 & 54 & 54 & 49 & 53 & 53 & Sub Saharan Africa & 50.4 \\
\hline Namibia & 51 & 52 & 53 & 49 & 48 & 48 & Sub Saharan Africa & 61 \\
\hline Mauritius & 50 & 54 & 53 & 54 & 52 & 57 & Sub Saharan Africa & 35.8 \\
\hline Sao Tome and Principe & 46 & 46 & 42 & 42 & 42 & 42 & Sub Saharan Africa & 30.8 \\
\hline Senegal & 45 & 45 & 44 & 43 & 41 & 36 & Sub Saharan Africa & 40.3 \\
\hline South Africa & 43 & 45 & 44 & 44 & 42 & 43 & Sub Saharan Africa & 63.40 \\
\hline Burkina Faso & 42 & 42 & 38 & 38 & 38 & 38 & Sub Saharan Africa & 35.3 \\
\hline Lesotho & 42 & 39 & 44 & 49 & 49 & 45 & Sub Saharan Africa & 54.2 \\
\hline Ghana & 40 & 43 & 47 & 48 & 46 & 45 & Sub Saharan Africa & 42.8 \\
\hline Benin & 39 & 36 & 37 & 39 & 36 & 36 & Sub Saharan Africa & 43.40 \\
\hline Swaziland & 39 & N/A & N/A & N/A & N/A & N/A & Sub Saharan Africa & 51.5 \\
\hline Zambia & 37 & 38 & 38 & 38 & 38 & 37 & Sub Saharan Africa & 55.6 \\
\hline Côte d'Ivoire & 36 & 34 & 32 & 32 & 27 & 29 & Sub Saharan Africa & $\mathrm{n} / \mathrm{a}$ \\
\hline Tanzania & 36 & 32 & 30 & 31 & 33 & 35 & Sub Saharan Africa & 37.8 \\
\hline Ethiopia & 35 & 34 & 33 & 33 & 33 & 33 & Sub Saharan Africa & 33.2 \\
\hline Niger & 33 & 35 & 34 & 35 & 34 & 33 & Sub Saharan Africa & 34.00 \\
\hline Gabon & 32 & 35 & 34 & 37 & 34 & 35 & Sub Saharan Africa & 42.2 \\
\hline Togo & 32 & 32 & 32 & 29 & 29 & 30 & Sub Saharan Africa & 46 \\
\hline Djibouti & 31 & 30 & 34 & 34 & 36 & 36 & Sub Saharan Africa & 44.1 \\
\hline Liberia & 31 & 37 & 37 & 37 & 38 & 41 & Sub Saharan Africa & 36.50 \\
\hline Malawi & 31 & 31 & 31 & 33 & 37 & 37 & Sub Saharan Africa & 46.1 \\
\hline Mali & 31 & 32 & 35 & 32 & 28 & 34 & Sub Saharan Africa & $\mathrm{n} / \mathrm{a}$ \\
\hline Gambia & 30 & 26 & 28 & 29 & 28 & 34 & Sub Saharan Africa & $\mathrm{n} / \mathrm{a}$ \\
\hline Sierra Leone & 30 & 30 & 29 & 31 & 30 & 31 & Sub Saharan Africa & 34 \\
\hline Kenya & 28 & 26 & 25 & 25 & 27 & 27 & Sub Saharan Africa & 48.5 \\
\hline Comoros & 27 & 24 & 26 & 26 & 28 & 28 & Sub Saharan Africa & $\mathrm{n} / \mathrm{a}$ \\
\hline Guinea & 27 & 27 & 25 & 25 & 24 & 24 & Sub Saharan Africa & 33.7 \\
\hline Nigeria & 27 & 28 & 26 & 27 & 25 & 27 & Sub Saharan Africa & 43 \\
\hline Uganda & 26 & 25 & 25 & 26 & 26 & 29 & Sub Saharan Africa & 41 \\
\hline Cameroon & 25 & 26 & 27 & 27 & 25 & 26 & Sub Saharan Africa & 46.50 \\
\hline Mozambique & 25 & 27 & 31 & 31 & 30 & 31 & Sub Saharan Africa & 45.6 \\
\hline Madagascar & 24 & 26 & 28 & 28 & 28 & 32 & Sub Saharan Africa & 42.6 \\
\hline Central African Republic & 23 & 20 & 24 & 24 & 25 & 26 & Sub Saharan Africa & 56.2 \\
\hline Burundi & 22 & 20 & 21 & 20 & 21 & 19 & Sub Saharan Africa & 33.4 \\
\hline Zimbabwe & 22 & 22 & 21 & 21 & 21 & 20 & Sub Saharan Africa & 43.1 \\
\hline $\begin{array}{l}\text { Democratic Republic of the } \\
\text { Congo }\end{array}$ & 21 & 21 & 22 & 22 & 22 & 21 & Sub Saharan Africa & $\mathrm{n} / \mathrm{a}$ \\
\hline Republic of Congo & 21 & 20 & 23 & 23 & 22 & 26 & Sub Saharan Africa & $\mathrm{n} / \mathrm{a}$ \\
\hline Chad & 20 & 20 & 22 & 22 & 19 & 19 & Sub Saharan Africa & 43.3 \\
\hline Eritrea & 20 & 18 & 18 & 18 & 20 & 25 & Sub Saharan Africa & $\mathrm{n} / \mathrm{a}$ \\
\hline Angola & 19 & 18 & 15 & 19 & 23 & 22 & Sub Saharan Africa & 42.70 \\
\hline Equatorial Guinea & 17 & N/A & N/A & N/A & N/A & N/A & Sub Saharan Africa & $\mathrm{n} / \mathrm{a}$ \\
\hline Guinea-Bissau & 17 & 16 & 17 & 19 & 19 & 25 & Sub Saharan Africa & 50.7 \\
\hline South Sudan & 12 & 11 & 15 & 15 & 14 & N/A & Sub Saharan Africa & 46.3 \\
\hline Somalia & 9 & 10 & 8 & 8 & 8 & 8 & Sub Saharan Africa & $\mathrm{n} / \mathrm{a}$ \\
\hline Average Sub Saharan Africa & 32.45 & 31.95 & 32.27 & 32.55 & 32.30 & 33.67 & & 44.39 \\
\hline
\end{tabular}

